(Pre-print final draft. The paper was published in: Information Economics and

Policy, Vol. 9, No. 4, 1997, pp. 271-290)

\title{
A COMPARISON AND CRITICAL ASSESSMENT OF PORAT AND RUBIN'S INFORMATION ECONOMY AND WALLIS AND NORTH'S TRANSACTION SECTOR
}

\author{
Hans-Jürgen Engelbrecht* \\ School of Applied and International Economics \\ Massey University \\ Palmerston North \\ New Zealand
}

\begin{abstract}
This paper compares two approaches to the measurement of the resources devoted to the organisational task in the economy, i.e. Porat and Rubin's 'Information Economy' and Wallis and North's 'Transaction Sector'. While there have been a number of studies using the information economy approach, it seems to have made way for a narrower focus on the information technology economy in recent years. The quantitative measurement of the transaction sector, on the other hand, again focuses on the wider issues involved in information activities, e.g. organisational and institutional questions. However, it is only in its infancy. Being based on a wellknown theory, i.e. transaction cost economics, it might attract attention from a larger number of economists than does the information economy approach. The paper points out similarities and shortcomings of both approaches and indicates areas for further research.
\end{abstract}

JEL classification: B4, L14, O51

Key words: $\quad$ Information economy; transaction sector; institutional and technological change, input-output analysis.

* Tel.: NZ 06-3569099, Fax: NZ 06-3505660, e-mail: H.Engelbrecht@massey.ac.nz.

An earlier version of this paper was presented at the European Association for Evolutionary Political Economy 1996 Conference, Antwerp, Belgium, 7-9 November. The author thanks participants, and especially John Adams, for their comments. Very useful comments were also received from John Wallis. The usual disclaimer applies. 


\section{INTRODUCTION}

When evaluating the contribution of transaction cost economics to economic analysis many authors have lamented the lack of empirical measurement, including leading proponents as well as critics of the approach (e.g., North, 1990, Harriss et al., 1995, Matthews, 1986). Wallis and North (1986) [henceforth WN] present a first attempt at empirically defining and measuring transaction costs in an economy-wide context. However, there is an earlier literature on the 'information economy' which is in many respects similar to WN's approach and which, so far, seems to have been ignored by transaction cost analysts.

This study compares WN's transaction sector with Porat and Rubin's (1977) [henceforth PR] information economy. Both approaches try to measure costs that are usually neglected in neoclassical analysis, i.e. information costs in the case of PR and transaction costs in the case of WN. Both provide not only aggregate data for the whole economy, but also industry level data, and both aim at changing the National Accounts by promoting the eventual integration of the information economy and the transaction sector into the framework in order to change our interpretation of economic growth. Similarities and shortcomings of both approaches will be pointed out, especially in regard to measuring the 'costs of organisation' in the economy.

Section 2 briefly comments on the distinction between transaction and information costs. Section 3 discusses PR's information economy. After introducing its definition and measurement, the literature based on PR's work is reviewed. This is followed by an evaluation of PR's approach. WN's transaction sector is the focus of Section 4. After introducing the definition and measurement of the sector, some further studies 
are discussed which highlight important issues concerning the relationship between institutional and technological change. This is followed by an evaluation of WN's approach. The final section contains concluding comments. Directions for further research are discussed in Sections 3.3., 4.3. and 5.

\section{TRANSACTION AND INFORMATION COSTS}

Transaction costs are defined by WN (1986) as the costs of making exchanges. More precisely, they can be described as the "costs that arise when individuals exchange ownership rights to economic assets and enforce their exclusive rights” (Eggertsson, 1990, p. 14). It is the consideration of the costliness of economic exchanges which distinguishes transaction cost theory from neoclassical theory. Such costs tend to increase over time in an economy with increasing specialisation and division of labour, i.e. with an increase in the volume and complexity of contracting (see North, 1990, for a detailed discussion of this issue).

Transaction cost economics is usually seen as an extension of neoclassical economics which widens the latter's range of applicability by considering how property-rights structures and transaction costs affect incentives and economic behaviour. Furubotn and Richter (1991) term this approach to the analysis of transaction costs "New Institutional Economics”. However, Eggertsson (1990, p. 6) reserves that term for institutional analysis which rejects core neoclassical assumptions, like the rational choice model, and uses the term "Neoinstitutional Economics" for transaction cost economics which extends the neoclassical model by relaxing the assumptions of full information and costless exchange. However, the boundaries between the two terms are fluid and "New Institutional Economics” (NIE) now seems to be widely accepted 
as a generic term that covers both New and Neo-Institutional Economics. Here we are mainly concerned with conceptual and measurement issues at the aggregate level which arise irrespective of whether or not one accepts the rational choice model.

Information costs are defined by PR as all costs associated with information activities, i.e. activities associated with the production, processing and distribution of information goods and services (PR, 1977, Vol. 1, p. 2), and they are also the key to the costs of transacting (North, 1990, p. 27). However, although information and transaction costs are intimately related, they are not always identical (Eggertson, 1990, p. 15):

“...transaction costs are in one way or another associated with the cost of acquiring information about exchange. But the concepts of information costs and transaction costs are not identical. A lonely person on a desert island will encounter information costs as he goes about his "home production", but an isolated individual does not engage in exchange and therefore will have no transaction costs.”

Realising that both total information costs and total transaction costs are, essentially, not measurable, PR and WN confine their analysis to costs which are related to production as measured in the National Accounts. In that case, the above distinction becomes irrelevant and the two measures are conceptually identical. There are, of course, differences in the actual measurement which arise from the way information and transaction costs are delineated, and from various trade-offs inevitable in empirical research. These are discussed below.

\section{DISCUSSION OF PORAT AND RUBIN'S INFORMATION ECONOMY}




\subsection{Definition and measurement}

PR try to assess the importance of information activities in the U.S. economy. They define information in a restricted sense: only information relating to production as measured in the National Accounts is included. Furthermore, the information economy is divided into two conceptually distinct components: the 'primary information sector' (PRIS) and the 'secondary information sector' (SIS).

The PRIS comprises goods and services which intrinsically convey information or which are directly useful in its production, processing and distribution and which, secondly, are transacted on established markets. The SIS accounts for the resources devoted to private and public bureaucracies which produce and consume information services 'in-house'. These non-marketed services are ancillary to the production of nonPRIS goods and services. To measure the SIS, non-PRIS firms and public bureaucracies are taken apart, in an accounting sense, into an information division (bureaucracy) and a non-information division (production). These firm divisions, or 'quasi-firms' (PR, 1977, Vol. 1), are aggregated to the sector level to, respectively, make up the SIS and noninformation sector of the economy. PR also integrate PRIS and SIS into an input-output (IO) framework, which enables structural analysis of the interaction of the information sectors, and of the interaction of information sectors with other sectors in the economy.

PRIS and SIS are measured in terms of value added, gross output and final demand. The data requirements to perform this task are formidable. However, measurement of the PRIS is relatively straightforward compared to that of the SIS. In some cases, an entire industry is identified as belonging to the PRIS, e.g. education, communication and electronic equipment. More often, only part of an industry's output is designated as 
informational. In that case, the original sector is decomposed into an information and non-information component by using the most detailed industry information available (see PR, 1977, Vol. 2). ${ }^{1}$

The problem of how to measure the non-marketed and therefore unrecorded output of the SIS is resolved by approximating it by its well-defined input costs: it is defined as the sum of employee compensation of information labour, informational physical capital (capital consumption allowance on information machines), and intermediate purchases of information goods and services (PR, 1977, Vol. 1, pp. 188-193).

The major SIS cost component is employee compensation. Its measurement requires a list of 'information occupations', i.e. occupations that are primarily concerned with the creation and handling of information. ${ }^{2}$ Using a detailed industry-times-occupation matrix

\footnotetext{
${ }^{1}$ PR provide the following broad typology of PRIS industries:
}

- Knowledge production and invention: Private R\&D and private information services.

- Information distribution and communication: For example education, public information services, telecommunications.

- Risk management: Insurance and finance industries and others.

- Search and coordination: Brokerage industries, advertising etc.

- Information processing and transmission services: Computer based information processing, telecommunications infrastructure etc.

- Information goods: Pencils, semiconductors, computers.

- Selected government activities: Education, postal service, others.

- Support facilities: Buildings, office furniture etc.

- Wholesale and retail trade in information goods and services.

These major classes are composed of hundreds of industries. Not all are counted as 100 percent informational. For example, insurance and finance was 84.1 percent informational in 1967, trade only 13.9 percent (for details, see PR, 1977, Vol. 2).

${ }^{2}$ Information occupations fall within the following major groups:

- Information producers: Scientific and technical workers, market search and coordination specialists, information gatherers, consultative service occupations.

- Information processors: Administrative, managerial, supervisory and clerical workers.

- Information distributors: Educators and communication workers. 
and a vector of average wages by occupation, PR determine information and noninformation employee compensation in each of the non-PRIS industries. ${ }^{3}$

The incorporation of the SIS into the IO table leaves the economy's total value added and final demand unchanged, but the value of intermediate inputs and outputs is increased by the SIS components. SIS output is mainly sold as intermediate input to other SISs and to the SISs' non-information counterparts. There can also be SIS sales to final demand, but this is a minor item (see PR, 1977, Vol. 1, for details). Karunaratne (1986) provides a mathematical exposition of the method used to rearrange the published IO tables in order to incorporate the PRIS and SIS.

Overall, PR found that the PRIS contributed 25.1 percent to GNP in 1967, and that the SIS accounted for another 21.1 percent. The total information economy was therefore estimated to account for over 46 percent of US GNP in 1967 (PR, 1977, Vol. 1, p. 8). Besides these ‘hard’ estimates, PR also provide an approximate time series of PRIS’s and SIS’s share in national income for the period 1929 to 1974 (ibid., Table 9.8, p. 167). While both sectors' share in GNP has increased over time, the increase was by no means steady. The SIS seems sensitive to recessions, and it contracted greatly during the Great Depression. Both sectors seem to have approximately constant GNP shares from the late 1960’s onwards. A further detailed study by Rubin and Taylor (1981) indicates that the PRIS's share in GNP was smaller in 1972 compared to 1967.

- Information infrastructure: Information machine workers, postal and telecommunication workers.

PR designate almost 200 out of over 420 occupations as, mostly 100 percent, informational. Twenty-eight occupations are judged as sufficiently mixed in nature to be counted as only 50 percent informational, e.g. physicians (see PR, 1977, Vol. 1, chapter 7). 


\subsection{Further analysis of the information economy}

PR's information economy concept was taken up by the OECD $(1981,1986)$ which asked member countries to provide data for both PRIS and SIS for a number of years and encouraged further analysis of the information economy and related issues. It gave rise to a large number of information economy studies for countries other than the U.S., including less developed countries (see, e.g., Engelbrecht, 1986a,b, Jussawalla et al., 1988, Kelkar et al., 1991; see also Lamberton, 1994, a pioneer in the economics of information (Lamberton, 1971) who has surveyed information economy research on several occasions).

Data generated by information economy studies can and have been analysed further, for example they have been incorporated into production function analysis (see, e.g., Hayes and Erickson, 1982, Warskett, 1984, Braunstein, 1986, Engelbrecht 1988, 1990), general equilibrium models (Engelbrecht, 1989/90, Karunaratne, 1991) and the analysis of manufacturing trade (Engelbrecht, 1991, 1994). An information economy has yet to be incorporated into a Social Accounting Matrix. In principle, the latter is extremely flexible and can incorporate much additional information. For example, it should be possible to include household activities. We might then be able to analyse how this large part of the 'unrecorded' economy is affected by the information economy.

However, from the start the OECD tried to use the information economy approach to analyse the impact of the new information and communication technologies. Coupled

\footnotetext{
${ }^{3} \mathrm{PR}$ also use detailed information to derive the other cost components. The interested reader is referred to PR (1977, Vol. 1).
} 
with the difficulty of measuring the SIS and the lack of an economic theory explaining this sector, this has led to an emphasis on the PRIS and the information ‘technology’ economy. As a result, since about 1986 the OECD has shifted its work away from PR's information economy concept towards other aspects of the information society, focusing on more narrowly information technology related issues (see OECD, 1993, and other volumes in the Information, Computer, Communications Policy series). Many other information economy analysts have also responded to the dramatic developments in information technology by becoming decidedly more technocentric (see, e.g., Miles, 1990, Imai, 1990).

\subsection{Evaluation of PR's approach}

On the one hand, PR's information economy provides a new perspective on structural change and highlights informational and organisational resource use issues. In contrast to the conventional accounting framework, shifts of information services production from SIS to PRIS and vice versa do not affect the total amount of services produced. By explicitly incorporating non-marketed information services, contracting out of information services is put into proper perspective. Adoption of the IO framework enables analysts to investigate the intersectoral relationships between the information economy and the rest of the economy. For example, it highlights the importance of intermediate demand instead of final demand for information services produced in the PRIS. Moreover, as pointed out in the previous section, information economy data have been analysed further using different methodologies and addressing a variety of questions. 
On the other hand, the information economy approach has been criticised for a variety of reasons. Many critics have emphasised that the information economy is too inclusive. It includes very diverse activities whose growth cannot be explained by a unitary theory. In particular, the inclusion of information goods production and its measurement have been questioned (see, e.g., Wellenius, 1988; Miles, 1990).

A related point concerns the difficulties of comparing PRISs and SISs internationally. Not only will the precise size of each sector in a country depend on the depth of detailed data available, but absence of a theory explaining information sector growth makes it difficult to compare the sector's size at different stages in the development process. Stating that the sector increases over time with the division of labour which gives rise to more complex organisational structures is not enough.

Unfortunately, some information economy advocates have tended to uncritically adopt a simplistic 'stages theory of development' in which the size of the information sector is directly linked to the level of economic development. A critique of this 'information sector hypothesis in development', which was, for example, advocated in United Nations (1986), is presented in Engelbrecht (1990). The contrary view that information sector growth leads to economic stagnation in developed countries has also been put forward (Voge, 1983), and it has also been dismissed as too simplistic (see, e.g., Piatier, 1984).

Others have provided a more differentiated picture. Katz (1986), for example, points out that the factors responsible for information sector growth, especially those concerning the SIS, differ greatly between developed and developing countries. In particular, he argues that information labour force growth in LDCs often occurs 
independently of manufacturing growth, the main reason being the growth in government information workers (public bureaucracies) which is due to political reasons. Far from being a sign of successful development, a large information sector in such countries might simply be a sign of bloated and inefficient public bureaucracies (Wellenius, 1988).

PR acknowledge their intellectual debt to Machlup’s (1962) pioneering study of the 'knowledge industry' in the U.S. ${ }^{4}$ However, Machlup (1980) was critical of PR's PRIS and SIS concept and their strict adherence to the National Accounts. He insisted that PRIS and SIS are two distinct approaches to the measurement of the information economy which should be strictly kept apart. In particular, he argued that the integration of the PRIS and SIS in one approach is not appropriate as it mixes information inputs in industries outside the PRIS with outputs of industries in that sector. ${ }^{5}$ This criticism also implies that PRIS and SIS value added should not be added to arrive at an overall estimate of the information economy's contribution to the economy. Rubin later seems to concur. He argues that it is necessary to net out the contribution of non-information labour from the PRIS before adding PRIS and SIS value added (Rubin, 1988, p. 109).

Similarly, Engelbrecht (1986, 1989/90) advocates measuring the SIS for every sector in the economy. It is unsatisfactory that PR measure the SIS only for part of the

\footnotetext{
${ }^{4}$ Machlup (1962) estimated that the knowledge industry accounted for 29 percent of GNP and employed 31 percent of the workforce in 1958.

${ }^{5}$ See Machlup (1980, p. 240). For a comparisons of Machlup's and PR's approaches, see Rubin and Huber (1986, chapter 2), PR (1977, Vol. 1) and Machlup (1980, chapter 14).
} 
economy, i.e. the non-PRIS industries. For example, a firm producing computer equipment and one producing cars both have private bureaucracies, but they are not measured equivalently. Also, PR's concept implies that the SIS can only be measured after the PRIS has been determined. Therefore, the SIS's size depends to a large part on the empirical delineation of the PRIS. The suggested redefinition of the SIS concept would have the advantage of facilitating measurement and analysis of the private and public bureaucracies without having to first derive the PRIS. ${ }^{6}$ This should redress the current imbalance in favour of information technology industry analysis and again put the emphasis on questions concerning organisational resource use, i.e. organisational design and the efficiency of different organisational structures.

PR acknowledge that every occupation has an informational component. Therefore, the designation of certain occupations as primarily informational is, to a certain extent, arbitrary. Moreover, many of today’s occupations did not exist 20 years ago, i.e. the list of information occupations needs regular updating. Schement (1990) carefully re-evaluates PR's delineation of information workers and finds that the information labour force grew significantly during the 1920's and 1930's, rather than the 1950's and 1960's as PR suggested, due to the expansion of U.S. corporate bureaucracies. He further argues that the 'information revolution' is therefore a byproduct of the industrial age, and that it does not indicate 'post-industrialism'.

\footnotetext{
${ }^{6}$ An example is Rabeau (1990), who estimates Canada's information economy by information worker value added in all sectors of the economy.

${ }^{7}$ In can be argued that by equating the information economy with post-industrial society PR have hindered the development of the information economy approach by associating it with futuristic post-industrial theories which, in hindsight, turned out to be wrong. It seems more appropriate to not distinguish between an industrial and post-industrial economy, but between different forms of knowledge-based industrial production (Castells and Aoyama, 1994).
} 
One can argue that a characteristic feature of an information economy is not just growth of the bureaucracies, but also the increasing information intensity of all material production processes. In that sense, PR exhibit 'industrial age' thinking by equating the SIS with the organisational task in the (non-PRIS) economy. Measuring the information economy in the information age would require distinguishing what amount of information labour value added in each industry is associated with the organisational task, and what amount is associated with the material production task, instead of assuming that all information labour is used for the former.

This last point reinforces the 'lack of theory' criticism. PR's information economy concept does not provide a theory to explain the development of advanced capitalist economies. What is missing are theories to explain the different components making up the information economy. In the following I focus on transaction cost economics, a theory which highlights the analysis and measurement of organisational resource use and which, while so far mainly focused on the micro-level, has also been applied at the economy-wide level. Its empirical measurement at that level has striking similarities to the measurement of the information economy. ${ }^{8}$

\section{DISCUSSION OF WALLIS AND NORTH'S TRANSACTION SECTOR}

\footnotetext{
${ }^{8}$ There are, of course, many micro-level theories trying to explain organisational structures (see, e.g., the survey by Radner, 1992, of neoclassical work on this subject and Groenewegen, 1996, on transaction cost and related 'alternative' theories). The latter regards transaction cost economics to be at the heart of the new theory of the firm. However, we are not trying to capture the richness of organisational changes which continuously occur at the micro (i.e. firm) level and which will partly balance out at the industry level. Rather, we focus on economy-wide measurement of organisational resource use and, due to the nature of the data, disaggregation to only the industry or sector level. Therefore, any analysis is restricted to organisational change and resource use issues which are detectable at that level of aggregation.
} 


\subsection{Definition and measurement}

WN's (1986) attempt at empirical measurement of transaction costs in an economywide context contrasts with Williamson (1985, p. 21/22) who eschews the direct measurement of transaction costs and regards them as basically unmeasurable. They first have to operationalise the notion of transaction costs before translating their transaction cost concept into measurable categories consistent with the available statistics (WN, 1986, p. 97):

"Every economic activity involves elements of transaction and other costs. Ideally our measure of transaction costs would delve into each exchange and separate these costs. Unfortunately, data are not available for such a measure. Instead our basic approach is to segregate economic activities and actors into those that are primarily associated with making exchanges and those that are not. The sum of the resources used by those associated with transacting make up our estimate of the transaction sector.”

WN's aim is to measure the changing size of the 'transaction sector' in the U.S. economy over the 1870 to 1970 period.

Any economic activity is made up of transaction costs and transformation costs, which are the costs associated with the transaction function and the transformation function. The latter 'transforms inputs into outputs'. As pointed out by Williamson (1979), the object is to economise on the sum of the two. WN measure transaction costs by the economic inputs used in performing the transaction function, i.e. the value of labour, land, capital and entrepreneurial skill. However, only transaction costs which result in the exchange of a marketed good or service, i.e. the purchase of 
'transaction services', are included in the transaction sector. This excludes, of course, a multitude of other transaction costs which are non-marketed, i.e. consumers investing time trying to find out about product characteristics etc. Therefore, WN do not measure the level of transaction costs in the economy as such. The size of their transaction sector is a lower bound estimate of the level of total transaction costs in a similar way that GNP is a lower bound estimate of activity in the economy. The way such transaction services are measured is very similar to PR's concept of the PRIS and SIS (WN, 1986, p. 103):

\begin{abstract}
"In order to measure the level of transaction services we focus on two basic types of measures, ... First, we include all of the resources used in providing transaction services in the open market. To do this we have classified certain types of economic activity as "transaction industries." These encompass the normal NIPA categories of Finance, Insurance, and Real Estate; Wholesale Trade; and Retail Trade ... Our second measure of transaction services includes transaction costs that occur within firms in nontransaction industries. To do this we divide occupations into those that provide primarily transaction services and those that provide primarily transformation services. We estimate the wages of employees in transaction occupations and use that as our measure of the transaction services provided by those workers and as an estimate of the size of the transaction sector in the nontransaction industries.”
\end{abstract}

Wholesale and retail trade (TRADE) also include some transformation activities, but they are not netted out (ibid., p. 102). WN are not certain whether protective services should be designated as a transaction industry, but they "feel uncomfortable putting...'protective services' into the nontransaction sector” (ibid., p. 102/3). They therefore include police, guards, sheriffs etc. in the transaction sector, but separately list their contribution to GNP. 
By far the largest groups of transaction occupations in the economy as a whole and in the 'in-house' transaction sector are managers, clerical and sales workers (see WN, 1986, Table 3.1, 3.2., p. 106/7). Therefore the intra-firm or 'in-house’ sector overlaps to a large extent with what is commonly understood to be the private bureaucracies or the management sector, and in this regard it is very similar to PR's SIS. ${ }^{9}$ Total transaction employment is estimated to have increased strongly over time, from about 17 percent in 1910 to about 39 percent in 1970 (ibid., p. 105). Moreover, the primary source of growth in transaction occupations were the nontransaction industries, i.e. the in-house sector.

It should be noted that in contrast to PR's SIS sector, the measure of the in-house transaction sector only includes transaction labour costs, but not other costs. ${ }^{10} \mathrm{WN}$ (ibid., p. 111) acknowledge that their neglect of capital resources associated with transaction workers may have biased their long-term time series comparisons. For example, it is likely that transaction workers worked with smaller amounts of capital in earlier years compared to later years. This point would seem to be even more important if WN were to update their study from 1970 to the present, in which case the huge investments in information technology which have occurred in private bureaucracies should be taken into account as part of that sector.

\footnotetext{
${ }^{9}$ Other transaction occupations are professionals processing information and making exchanges (accountants, lawyers, judges, notaries) and service workers protecting property rights (police, guards, watchmen) and some other groups like farm managers, foremen etc. (see WN, 1986, for further details).

${ }^{10}$ Another shortcut compared to PR is WN's use of the ratio of 'transaction workers to other workers' for each industry to determine the proportion of the wage bill accounted for by each group. The sum of all industry transaction worker wage bills then constitutes the measure of the size for the 'in-house' transaction sector. This will have tended to bias the size of this sector downwards if the transaction workers' true share of the wage bill was larger than their share in employment.
} 
Government also provides both transaction and transformation services, and the latter include an 'in-house' transaction component. This in-house component is measured in the same way as that for the private sector, i.e. it is approximated by the employee compensation of transaction workers in the non-transaction parts of government activities. It is then added to the total resource use of government transaction services to obtain the estimate for the total public transaction economy (ibid., p. 119). However, it is often difficult to distinguish public transaction from public transformation services, especially in regard to defence expenditure, and WN have to make a number of simplifying assumptions to arrive at their estimate. Therefore, they also provide an alternative estimate by treating all of government as a nontransaction industry, and calculating the in-house component in the usual way. This provides a minimum estimate of the transaction sector in government.

Overall, WN estimate that the transaction sector grew fairly steadily from about a quarter of GNP in 1870 to about 47 or 55 percent in 1970, depending on how the public sector component of the transaction sector is measured (ibid., Table 3.13, p. 121). WN argue that their findings are important for the study of the relationship between institutional structures and economic growth (WN, 1986, pp. 123-125):

“... the study of institutional structures and economic growth has not enjoyed the melding of statistical inquiry, theoretical formulation, and historical analysis that technology and human capital have received. For the most part institutions are treated theoretically as a kind of disembodied factor: the rules of the game rather than the actual players.

Institutions, however, are not just rules, they require labor, capital, and other real resources in order to operate. The approach in this paper provides important information on the actual costs of implementing institutional structures....The growth of the transaction sector is a structural change of the first order." 
They particularly refer to the need to further analyse the role of the in-house transaction sector in economic growth.

\subsection{Some further transaction sector studies}

So far there are very few empirical studies based explicitly on WN's transaction sector concept, although there are many studies which can be interpreted as fitting within it, for example studies which include private bureaucracies as a determinant of the manufacturing trade structure (e.g., Engelbrecht, 1991, 1994, forthcoming). ${ }^{11}$

Here I want to focus on two transaction sector studies by Fuess and van den Berg (1992, 1996) because they highlight some important issues about the relationship between institutional and technological change. Their first study assesses the likely impact of the growth of transaction industries on the measurement of productivity growth in the U.S. economy. They subtract all transaction industries from GNP to obtain a series of adjusted GNP, calculate productivity growth for both series, and conclude that the growth of such industries has thwarted U.S. productivity growth, particularly during the 1980s. Fuess and van den Berg refine their adjustment of published GNP figures in their second study by also taking into account non-marketed household production and the underground economy. They conclude that conventional GNP growth figures have exaggerated improvements in actual output due to the combined effect of both factors, and indicate the pattern of variation for the 1950-1989 period.

\footnotetext{
${ }^{11}$ A preliminary study which explicitly analyses how the in-house transaction sector of U.S. manufacturing industries was affected by foreign trade during the 1985-89 period is Engelbrecht (1995). There is also a lot of empirical micro-level transaction cost economics research (see, for example, the survey by Masten, 1996).
} 
These studies come very close to adopting the Marxian view of regarding transaction services as unproductive activities. ${ }^{12}$ However, Wallis and North (1988) argue explicitly that the kind of simple GNP adjustment used by Fuess and van den Berg is unwarranted because most transaction sector services are intermediate, not final, goods. Only final transaction sector goods should be subtracted from conventionally measured GNP. Wallis and North (1988, Table2, p. 653) also provide data on the empirical importance of wrong GNP adjustment. It is shown to greatly distort GNP levels and economic growth rates.

Fuess and van den Berg can also be interpreted as working within the Coasian tradition in which institutions are chosen to minimise transaction costs, subject to a given production (i.e. transformation) technology. North and Wallis (1994) ${ }^{13}$ are highly critical of Coase (1937), Williamson (1985) and Chandler (1977) adopting this conceptualisation of the relationship between institutional change and production technology. ${ }^{14}$ They ask "what happens when technologies are not given? What happens when technologies and institutions are simultaneously chosen?” (North and

12 See, for example, Wolff (1987). His unproductive sectors include all transaction industries (ibid., Table 2.1, p. 43).

13 See North (1981) for an earlier statement of these points. See also Englander's (1988) criticism of Williamson's treatment of technology, and Williamson's (1988) reply.

${ }^{14}$ For example, North and Wallis (1994, p. 615) argue that "The critical weakness in Williamson's approach is that all changes in observable costs must, by construction, come from what he calls 'neoclassical production costs' and we call transformation costs. In a Williamson world we can only explain institutional change as the result of that technical change that alters neoclassical production costs since they are the only observable costs, or as the result of traditional relative price changes. Any explanation that suggests that transaction costs change independently of changing production functions is empirically unsupportable, since we do not, cannot, and need not observe transaction costs.” 
Wallis, 1994, p. 610). In that case, institutions will be chosen to minimise total costs, given the level of output. They further argue that this (North and Wallis, 1994, pp. 610/11):

“...suggests a new historical perspective on the relationship between technical and institutional change. It questions whether the growth enhancing effects of technical change - driving down transformation costs - are ultimately limited by the rising transaction costs associated with the institutional changes necessary to implement new technologies. While the process may work this way in some sectors of the economy, in other sectors technical change may lower transaction costs, not raise them. In other cases institutional change may raise transaction costs if, at the same time, it lowers transformation costs. This is a fundamental revision of the basic way in which economists and economic historians think about the process of economic growth. Rather than viewing institutional change as a way of implementing technical change, our framework allows for institutional change to be an important and independent source of growth. Technical change also has a broader impact, sometimes changing transformation costs, but sometimes changing transaction costs directly.”

Therefore, the level of resources used for transaction services alone does not enable us to draw conclusions about the efficiency of provision, either in-house or in the transaction industries, and they should not be seen as independent from material production in the sense that they can be subtracted from GNP without affecting 'real' output. Of course, transaction services may be provided inefficiently, i.e. at any particular point in time institutions and organisations might not effectively economise on transaction costs for a variety of reasons. However, analysts who regard a large transaction (or information) sector as either beneficial or detrimental per se miss the point.

\subsection{Evaluation of WN's approach}


Many of the criticisms of the information economy discussed in Section 3.3 also apply to the transaction sector. For example, the same criticisms that have been made of the selection of information occupations have also been made in regard to transaction employment (Davis, 1986). I do not regard this criticism as invalidating the whole approach. It does imply that the list of transaction occupations needs to be updated at regular intervals, and that the most detailed information available on job characteristics should be used in the process.

However, important measurement issues remain in regard to the division of defence and other government expenditure into a transformation and transaction component. Davis (1986, p.157) is especially critical of WN's willingness, in principle, to treat a proportion of such expenditure as belonging to the transaction sector. Also, the way WN estimate the in-house sector involves more shortcuts than PR use, and they neglect to include inputs other than labour that are used for transaction purposes, i.e. physical capital and other value added components. ${ }^{15}$

The way the sectoral coverage of the in-house sector depends on how transaction or PRIS industries are delineated is a characteristic feature of both WN's and PR's approaches. In hindsight, it is also one of their main weaknesses. It is surprising that despite this fundamental similarity in methodology and the empirical overlap of both

15 They acknowledge that their measurement of the 'in-house' transaction sector could be improved if wage, hour, and employment data for specific occupations within industries were used (WN, 1986, p. 111). The simplified measurement compared to PR was also due to the fact that WN tried to develop a consistent time series, stretching from 1870 to 1970 . Wallis points out that use of more sophisticated estimation methods for later years would have introduced additional comparability problems (personal communication with John Wallis). 
approaches, particularly with regard to the in-house sector, WN do not provide any reference to PR's work. Personal communication with John Wallis indicates that they were simply not aware of it.

Many problems remain in regard to the empirical measurement and analysis of transaction costs. I submit that the greatest strength of WN's work is to focus our attention on quantitative issues concerning institutions and institutional design in general, and private bureaucracies and organisational resource use in particular. However, the in-house sector concept has to be made logically consistent and its operationality has to be improved. A first step would be the measurement of the private bureaucracies in a consistent way for all sectors in the economy.

A lot more attention has to be given to the interrelationship between transformation (i.e. production) sectors and their (private and public) bureaucracies. ${ }^{16}$ North and Wallis (1994, p. 617) point out that if both sides are given equal standing in the analysis, productivity changes can come from a variety of sources. There can be:

1. Transaction augmenting institutional change, i.e. institutional change that raises the productivity of transaction inputs.

2. Transaction augmenting technical change, i.e. technical change that raises the productivity of transaction inputs.

3. Transformation augmenting institutional change, i.e. institutional change that raises the productivity of transformation inputs.

${ }^{16}$ This point was also made by Englander (1988, p. 340): "I propose that a more analytically and historically complete understanding of technology and transaction costs occurs when we examine their historically-specific interrelationship rather than give pre-eminence to either one”. 
4. Transformation augmenting technical change, i.e. technical change that raises the productivity of transformation inputs.

In addition, one also has to allow for the possibility of negative productivity change, for example an increase in institutional and organisational inefficiency, due to institutional and organisational inertia and path dependency. ${ }^{17}$ One reason for organisational inertia might be the erosion (depreciation) of existing institutional and organisational capital associated with the adoption of new technologies, i.e. the process of 'Schumpeterian informational creative destruction’ (Jones and Newman, 1995), and issues concerning technological absorptive capacity and learning in general (North, 1994).

North and Wallis (1994) also point out that one has to distinguish between the impact of an invention on productivity in the originating industry and its effects on other industries. For example, the development of more powerful computers is a transformation augmenting technical change in the computer hardware industry, but for industries using the new computers, it will typically constitute transaction augmenting technical change. ${ }^{18}$ North and Wallis (1994) recognise the importance of intermediate goods (and services), and the need to go beyond the analysis of a particular firm or industry: "The role of intermediate goods, both in the transaction

${ }^{17}$ David (1994) has commented that the question of 'why history matters' in the evolution of organisations and institutions has been neglected by New Institutional economists. He urges more research into the workings of the evolutionary processes. Some authors have questioned whether the transaction cost approach can incorporate institutional and organisational change (see, e.g., several of the contributions in Groenewegen, 1996).

${ }^{18}$ North and Wallis (1994, p. 621/22) use their model of the different sources of productivity change to recast Chandler's account of the growth of large firms and argue that the trigger for the growth of large business enterprises was indeed transaction augmenting technical change transmitted via intermediate inputs, and subsequent growth was due to transformation and transaction augmenting institutional change. 
and transformation process, is central to understanding how technical and institutional change are transmitted throughout the economy ... institutional change in one industry can be transmitted to another industry via intermediate goods” (ibid., p. 618).

The next logical step in the analysis of the transaction sector would therefore be its incorporation into an IO framework which would enable one to trace and analyse these inter-industry interactions. We have come full circle back to PR who not only measure their in-house sector but also analyse the structural relationships between this sector and the rest of the economy using the IO framework. ${ }^{19}$

\section{CONCLUDING COMMENTS}

It is commonplace to say that many of the kind of jobs available in, say, 30 years time have not yet been invented. It is most likely that the vast majority of these jobs will fall into the information/transaction services category, reflecting the general increase in the division of labour and information intensity of every economic activity.

An important aim of this paper has been to draw the attention of New Institutional economists who are interested in empirical measurement and analysis of transaction costs to the information economy literature which predates WN's attempt to measure the transaction sector. The two approaches are conceptually very similar and could benefit from taking note of each other. Although there are large differences between PRIS industries and transaction industries, the in-house components of the

\footnotetext{
${ }^{19}$ The need for structural analysis is also indicated by the fact that there are large differences in size and composition of the information/transaction labour forces, even amongst G-7 countries (Castells and Aoyama, 1994).
} 
information and transaction economy which both try to account for organisational resource use are much more similar.

The information economy approach is too broad and lacks a firm basis in economic theory to make it acceptable to a wider audience of economists. The original tension between focusing on the impact of information and communication technologies and on the resource use for informational purposes in general seems to have been resolved in favour of the information technology economy approach. Transaction cost theory provides a theoretical underpinning of the second major focus of the information economy approach, i.e. public and private bureaucracies.

Both approaches can be criticised for unsatisfactorily accounting for the in-house component. If the aim is to measure organisational resource use one cannot mix the occupation (input based) approach with the industry (output based) approach. While the combined approaches seem to satisfy the analysts' desire to capture the total information economy or the total transaction sector in the economy and come up with some headline catching overall percentage, they are nevertheless erroneous and have resulted in delaying and confusing the quantitative analysis of the organisational task proper which by any measure accounts for a large proportion of all resources used in today’s advanced economies.

I regard the incorporation of an amended transaction sector into an IO framework as a useful next step in the quantitative analysis of the 'costs of running the economic system'. This would enable researchers to bring a wide range of IO techniques to bear on the analysis of the role of the transaction sector in the economy. Further extension to a Social Accounting Matrix approach would enable researchers to widen the scope 
of analysis, for example by explicitly including households. Bianchi (1995) has argued that the transaction and information cost approach to the firm neglects the firm's role as a learning organisation which adopts to changing environments and innovates. However, use of an IO based framework does not preclude the analysis of dynamic effects (an example of how the study of innovation and inter-industrial analysis may be reconciled is DeBresson, 1996).

These developments would provide welcome steps towards a quantitative analysis of the interactions between institutions, organisations and economic structure in economic history, enabling us to address a variety of policy issues while giving due weight to institutional factors. This does not imply that the author subscribes to a 'Grand Theory' of development based on the NIE which, given our current state of knowledge, would be premature at best and most likely be inappropriate and deeply misleading. ${ }^{20}$ The aim is simply to advance the actual measurement and quantitative analysis of transaction costs, which many commentators regard as an underdeveloped aspect of the NIE. It is hoped that this paper is a small contribution to remedying this state of affairs.

${ }^{20}$ See, for example, the volume edited by Harriss et al. (1995) who focus on the contribution of the NIE to development studies and who provide a critique of NIE from a wider social science perspective. 


\section{REFERENCES:}

Bianchi, Marina (1995), "Markets and Firms: Transaction Costs versus Strategic Innovation”, Journal of Economic Behavior and Organization, Vol. 28, No. 2, October, pp. 183-202.

Braunstein, Yale M. (1986), "Information as a Factor of Production: Substitutability and Productivity”, Information Society, Vol. 3, No. 3, pp. 261-273.

Castells, Manuel and Yuko Aoyama (1994), "Paths Towards the Informational Society: Employment Structure in G-7 Countries, 1920-90", International Labour Review, Vol. 133, No. 1, pp. 5-33.

Chandler, Alfred D. (1977), The Visible Hand, Cambridge, MA: Belknap Press of Harvard University Press.

Coase, R. H. (1937), “The Nature of the Firm”, Economica, Vol. 4, November, pp. 386-405.

David, Paul A. (1994), "Why are Institutions the 'Carriers of History'?: Path Dependence and the Evolution of Conventions, Organizations and Institutions", Structural Change and Economic Dynamics, Vol. 5, No. 2, December, pp. 205-220.

Davis, Lance E. (1986), “Comment”, in: Stanley Engerman and Robert Gallman (eds.), Long-Term Factors in American Economic Growth, NBER Studies in Income and Wealth Vol. 51, Chicago: The University of Chicago Press, pp. 149-161.

DeBresson, Christian (1996), Economic Interdependence and Innovative Activity: An Input-Output Analysis, Cheltenham: Edward Elgar.

Eggertsson, Thrainn (1990), Economic Behavior and Institutions, Cambridge, U.K.: Cambridge University Press.

Engelbrecht, Hans-Jürgen (forthcoming), "Corporate Bureaucracies and United States Competitiveness", International Journal of the Economics of Business.

Engelbrecht, Hans-Jürgen (1995), “The Impact of International Trade on the 'In-House' Transaction Sector: Evidence from the United States, 1985-89”, Applied Economics Letters, Vol. 2, pp. 60-63.

Engelbrecht, Hans-Jürgen (1994), "Private Bureaucracies, Organizational Efficiency, and Australia's Manufacturing Trade Structure: A Comparison with Japan”, International Review of Applied Economics, Vol. 8, No. 3, September, pp. 266-282.

Engelbrecht, Hans-Jürgen (1991), "Information Services, Private Bureaucracies, and Japan's Comparative Advantage”, Review of Economics and Statistics, Vol. LXXIII, No. 4, November, pp. 716-719. 
Engelbrecht, Hans-Jürgen (1990), “A Comparative Analysis of the Use of Information Inputs in the Manufacturing Sectors of Korea and Japan”, World Development, Vol. 18, No. 1, January, 77-89.

Engelbrecht, Hans-Jürgen (1989/90), "In-House Information Activities in an Applied General Equilibrium Framework”, Information Economics and Policy, Vol. 4, No. 4, pp. 305-323.

Engelbrecht, Hans-Jürgen (1988), "Information Resources in U.S. Manufacturing: A Reassessment”, Information Society, Vol. 5, No. 3, pp. 147-159.

Engelbrecht, Hans-Jürgen (1986a), “The Japanese Information Economy: Its Quantification and Analysis in a Macroeconomic Framework (with Comparisons to the U.S.)”, Information Economics and Policy, Vol. 2, No. 4, pp. 277-306.

Engelbrecht, Hans-Jürgen (1986b), "From Newly Industrialising to Newly Informatising Country: The Primary Information Sector of the Republic of Korea 1975-1980", Information Economics and Policy, Vol. 2, No. 3, pp. 169-194.

Englander, Ernest J. (1988), “Technology and Oliver Williamson’s Transaction Cost Economics”, Journal of Economic Behavior and Organization, Vol. 10, No. 3, October, pp. 339-353.

Fuess, Jr., Scott M. and Hendrik van den Berg (1996), "Does GNP Exaggerate Growth in "Actual” Output? The Case of the United States", Review of Income and Wealth, Series 42, Number 1, March, pp. 35-48.

Fuess, Jr., Scott M. and Hendrik van den Berg (1992), “The Impact of Transaction Activities on U.S. Productivity Growth”, Economics Letters, Vol. 38, No. 2, February, pp. 243-247.

Furubotn, Eirik G. and Rudolf Richter (1991), “The New Institutional Economics: An Assessment”, in: Eirik G. Furubotn and Rudolf Richter (eds.), The New Institutional Economics: A Collection of Articels from the Journal of Institutional and Theoretical Economics, College Station: Texas A\&M University Press, pp. 1-32.

Groenewegen, John (1996), Transaction Cost Economics and Beyond, Dordrecht: Kluwer Academic Publishers.

Harriss, John, Hunter, Janet and Colin M. Lewis (1995), The New Institutional Economics and Third World Development, London and New York: Routledge.

Hayes, Robert M. and Timothy Erickson (1982), "Added Value as a function of purchases of information services”, Information Society, Vol. 1, No. 4, pp. 307-338.

Imai, Ken-ichi (1990), "The Information Industry”, chapter 5 in: Soesastro, Hadi and Mari Pangestu (eds.), Technological Challenge in the Asia-Pacific Economy, Sydney: Allen \& Unwin, pp. 74-89. 
Jones, Robert and Geoffrey Newman (1995), “Adaptive Capital, Information Depreciation and Schumpeterian Growth”, Economic Journal, Vol. 105, No. 431, July, pp. 897-915.

Jussawalla, Meheroo, Donald M. Lamberton and Neil D. Karunaratne (eds.) (1988), The Cost of Thinking: Information Economies of Ten Pacific Countries, Norwood, N.J.: Ablex.

Karunaratne, Neil D. (1991), "A General Equilibrium Analysis of the Australian Information Economy”, Economic Systems Research, Vol. 3, No. 2, pp. 171-185.

Karunaratne, Neil D. (1986), "An Input-Output Approach to the Measurement of the Information Economy”, Economics of Planning, Vol. 20, No. 2, pp. 87-103.

Katz, Raul L. (1986), "Explaining Information Sector Growth in Developing Countries”, Telecommunications Policy, Vol. 10, No. 3, September, pp. 209-228.

Kelkar, Vijay L., Chaturvedi, Devendra N. and Madhav K. Dar (1991), “India's Information Economy: Role, Size and Scope", Economic and Political Weekly, September 14, pp. 2153-2161.

Lamberton, D. McL. (1994), “The Information Economy Revisited”, chapter one in: Robert E. Babe (ed.), Information and Communication Economics, Boston: Kluwer Academic Publishers, pp. 1-33.

Lamberton, D. McL. (ed.) (1971), Economics of Information and Knowledge, Harmondsworth, U.K.: Penguin Books.

Machlup, Fritz (1980), Knowledge: Its Creation, Distribution, and Economic Significance, Vol. 1: Knowledge and Knowledge Production, Princeton, N.J.: Princeton University Press.

Machlup, Fritz (1962), The Production and Distribution of Knowledge in the United States, Princeton, N.J.: Princeton University Press.

Masten, Scott E. (1996), "Empirical Research in Transaction Cost Economics: Challenges, Progress, Directions”, chapter three in: John Groenewegen (ed.), Transaction Cost Economics and Beyond, Dordrecht: Kluwer Academic Publishers, pp. 43-64.

Matthews, R. C. O. (1986), “The Economics of Institutions and the Sources of Growth”, Economic Journal, Vol. 96, No. 384, December, pp. 903-918.

Miles, Ian (1990), Mapping and Measuring the Information Economy, Library and Information Research Report 77, British Library Board.

North, Douglass C. (1994), "Economic Performance Through Time”, American Economic Review, Vol. 84, No. 3, June, pp. 359-368.

North, Douglass C. (1990), Institutions, Institutional Change and Economic Performance, Cambridge: Cambridge University Press. 
North, Douglass C. and John J. Wallis (1994), "Integrating Institutional Change and Technical Change in Economic History: A Transaction Cost Approach”, Journal of Institutional and Theoretical Economics, Vol. 150, No. 4, pp. 609-624.

OECD (1993), Usage Indicators: A New Foundation for Information Technology Policies, Information Computer Communications Policy Report 31, Paris.

OECD (1986), Trends in the Information Economy, Information Computer Communications Policy Report 11, Paris.

OECD (1981), Information Activities, Electronics and Telecommunications Technologies, Vol. I: Impact on Employment, Growth and Trade, Information Computer Communications Policy Report 6, Paris.

Piatier, André (1984), “Innovation, Information and Long-Term Growth”, chapter 16 in: Christopher Freeman (ed.), Long Waves in the World Economy, London: Frances Pinter.

Porat, Marc Uri and Michael Rogers Rubin (1977), The Information Economy, in nine volumes, Office of Telecommunications Special Publication 77-12, US Department of Commerce, Washington D.C.: Government Printing Office.

Rabeau, Yves (1990), The Information Economy in Canada: An "Input-Output" Approach, Laval: Department of Communications of Canada.

Radner, Roy (1992), "Hierarchy: The Economics of Managing”, Journal of Economic Literature, Vol. XXX, No. 3, September, pp. 1382-1415.

Rubin, Michael R. (1988), "The Secondary Information Sector: Its Meaning, Measurement, and Importance”, chapter 9 in: Jussawalla, Meheroo, Donald M. Lamberton and Neil D. Karunaratne (eds.), The Cost of Thinking: Information Economies of Ten Pacific Countries, Norwood, N.J.: Ablex, pp. 101-110.

Rubin, Michael R. and Mary T. Huber (1986), The Knowledge Industry in the United States 1960-1980, Princeton, N.J.: Princeton University Press.

Rubin, Michael R. and Elizabeth Taylor (1981), "The U.S. Information Sector and GNP: An Input-Output Study”, Information Processing and Management, Vol. 17, pp. 163-194.

Schement, Jorge Reina (1990), "Porat, Bell, and the Information Society Reconsidered: The Growth of Information Work in the Early Twentieth Century”, Information Processing and Management, Vol. 26, No. 4, pp. 449-465.

United Nations, Centre for Science and Technology for Development (1986), “New Information Technologies and Development", Bulletin for the Advance Technology Alert System, Issue 3.

Voge, Jean (1983), "The Political Economics of Complexity: From the Information Economy to the 'Complexity' Economy”, Information Economics and Policy, Vol. 1, pp. 97-114. 
Wallis, John Joseph and Douglass C. North (1988), "Should Transaction Costs be Subtracted from Gross National Product?”, Journal of Economic History, Vol. XLVIII, No. 3, September, pp. 651-654.

Wallis, John Joseph and Douglass C. North (1986), "Measuring the Transaction Sector in the American Economy, 1870-1970", chapter three in: Stanley Engerman and Robert Gallman (eds.), Long-Term Factors in American Economic Growth, NBER Studies in Income and Wealth Vol. 51, Chicago: The University of Chicago Press, pp. 95-148.

Warskett, George (1984), "The Role of Information Activities in Total Canadian Manufacturing: Separability and Substitutability”, Applied Economics, Vol. 16, No. 5, October, pp. 763-770.

Wellenius, Bjorn (1988), "Foreword: Concepts and Issues on Information Sector Measurement”, in: Jussawalla, Meheroo, Donald M. Lamberton and Neil D. Karunaratne (eds.), The Cost of Thinking: Information Economies of Ten Pacific Countries, Norwood, N.J.: Ablex, pp. vii-xii.

Williamson, Oliver E. (1988), "Technology and Transaction Cost Economics: A Reply”, Journal of Economic Behavior and Organization, Vol. 10, No. 3, October, pp. 355-363.

Williamson, Oliver E. (1985), The Economic Institutions of Capitalism: Firms, Markets, Relational Contracting, New York: Free Press.

Williamson, Oliver E. (1979), "Transaction-Cost Economics: The Governance of Contractual Relations”, Journal of Law and Economics, Vol. 22, October, pp. 233260.

Wolff, Edward N. (1987), Growth, Accumulation, and Unproductive Activity: An Analysis of the Postwar U.S. Economy, New York: Cambridge University Press. 